\title{
Leucas zeylanica is a Bangladeshi plant with significant medicinal prospect: A review
}

\author{
Md. Islam Molla *and Sabiha Parvin Ela \\ Department of Pharmacy, Jagannath University, Dhaka-1100, Bangladesh.
}

GSC Biological and Pharmaceutical Sciences, 2021, 16(01), 011-018

Publication history: Received on 26 May 2021; revised on 02 July 2021; accepted on 06 July 2021

Article DOI: https://doi.org/10.30574/gscbps.2021.16.1.0184

\begin{abstract}
Leucas zeylanica is one of the most precious gifts of nature to the entire civilization. It offers folkloric system a dependable option to heal numerous diseases like- burning urination, toothaches, common skin diseases, gout, inflammatory conditions, rheumatic diseases, abdominal pain, worms, anorexia, colic, flatulence, etc. Many of these ancient practices have got their scientific resemblances like- using as an agent for treating common pains, oxidative stresses, microbial infections, sleep disorders, inflammations, gout associated pains, thrombosis and sunlight related skin damages. Some researchers also isolated a huge bunch of vital phytochemicals like- torosaflavone A, drymariatin C, daidzein, luteolin $3^{\prime}, 4^{\prime}$-dimethyl ether, apigenin, tricin, chrysoeriol, linarigenin, $\beta$-sitosterol, stigmasterol, hexadecanoic acid, octadecanoic acid, 9,12,15- octadecatrienoic acid, farnesene, $\beta$-caryophyllene, caryophyllene oxide, phytol, $\beta$-cubebene, $\alpha$-selinene, $\alpha$-tocopherol etc. from different crude extracts of Leucas zeylanica. Making proper correlation between these phytoconstituents with the general utilizations of this plant will assist scientists to develop auspicious lead compounds. This review covers a summary of ethnomedicinal, phytochemical and biological studies of several crude preparations of Leucas zeylanica.
\end{abstract}

Keywords: Leucas zeylanica; Folkloric system; Phytoconstituents; Pharmacological activities; Lead compounds

\section{Introduction}

Nature provides humankind with an enormous and trustworthy source of medicinal plants that are comparatively safe and efficacious in many diseases in their usual forms or need to be chemically modified [1-3]. Before the advancement of medical sciences, plant parts were the only hope to get healed from a diseased condition. Researchers always attempt to verify and rationalize traditional practices of natural substances in scientific ways to develop new pharmaceuticals $[4,5]$. Along with exploration of scientific rationale of traditional uses, unwanted and noxious substances are also marked in a herbal preparation [6]. Phytochemicals identified in a plant extract show scientists an optimistic path to develop novel lead compounds of medicinal importance [7]. The procedures of treatment with herbal products have been experiencing notable modifications that enable them to become stronger and more potent than earlier in human health management [8-11].

L. zeylanica, commonly recognized as Ceylon Slitwort, is an important species of the renowned genus Leucas that contains 80 species [12]. Usually these plants are highly distributed in East Africa and Asia including- India, Bangladesh, Nepal, Sri Lanka, Myanmar and China. L. zeylanica belongs to the well-known plant family- Lamiaceae and is an erect type annual herb with a height up to $50 \mathrm{~cm}$ [13]. Usually, it grows on dry and sunny areas like- sea beach, waste sites, paddy fields and, roadsides.

\footnotetext{
* Corresponding author: Md. Islam Molla; Email:islam.mollah@gmail.com

Department of Pharmacy, Jagannath University, Dhaka-1100, Bangladesh.
} 


\section{Traditional Uses}

Drug scientists are highly grateful to the traditional practitioners since they are continuously guiding to the probable sources of new medicines. L. zeylanica is one of the utmost popular plants of ethnomedicinal importance [14-16]. Generally, it is utilized as a reliable treatment choice for common skin diseases, burning urination, toothaches, gout, inflammatory conditions, rheumatic diseases, thrombus like conditions, abdominal pain, worms, cold, anorexia, colic, flatulence, malaria and abdominal skin tightening after delivery [17-19].

Different parts like- leaf, root and whole plant of L. zeylanica are reported to be utilized in different diseased conditions. Whole plants are chosen in headache, cold, scabies, and skin diseases [20]. Juice extracted from leaves is assumed to be helpful in snakebite [21]. Decoction of L. zeylanica leaves with seeds of Nigella or turmeric juice and rice is applied on nose ulcers as a lotion like preparation [22]. In India, leaf is used in jaundice, fever, and snake and scorpion bites [23]. Moreover, leaf paste is taken orally by Marma community in Bangladesh to treat burning urination [24]. Interestingly, a necklet type ornament made up of L. zeylanica roots is worn on legs and arms in Bangladesh with a belief to get healed from fever related convulsion [25].

A number of abovementioned local uses of L. zeylanica have already been verified while others are needed to be justified.

\section{Phytochemical Properties}

Leucas is the name of a genus of enormous potential phytoconstituents. Most probably, the first exploration on phytoconstituents of this genus started in 1947 [26]. Till now, a huge bunch of chemicals have been informed in this genus. Like other species, L. zeylanica is also a potential basis of many pharmaceutically important phytoconstituents. Some research groups found positive results for alkaloids, glycosides, tannins, flavonoids, carbohydrates, and steroids with conventional phytochemical screening procedures [27-30].

Analysis of dichloromethane whole plant extract of L. zeylanica with GC-MS identified fatty acids $(9,12$, -octadecadienoic acid, hexadecanoic acid, octadecanoic acid, 9,12,5- octadecatrienoic acid), sesquiterpenes (farnesene, $\beta$-caryophyllene, caryophyllene oxide), phytol, neophytadiene, $\beta$-cubebene, $\alpha$-selinene and, $\alpha$-tocopherol [31]. GC-MS analysis of nhexane extract (whole plants) reported caryophyllene oxide, (3, 7, 11, 15)-tetramethyl-2-hexadecen-1-ol, neophytadiene, hexadecanoic acid, octadecanoic acid, phytol, 4,8,12,16-tetramethylheptadecan-4-olide, stigmasterol, $\beta$ sitosterol and, $\alpha$-tocopherol [31].

An investigation on L. zeylanica methanol extract (aerial parts) isolated three important chemicals- 12-0- $\beta$-Dglucopyranosyl-11, 16-dihydroxyabieta-8, 11, 13-triene, 12, 19-0- $\beta$-D-diglucopyranosyl-11, 16-dihydroxyabieta-8, 11, 13-triene and, 19-0- $\beta$-D-carboxyglucopyranosyl-12-0- $\beta$-D-glucopyranosyl-11,16-dihydroxyabieta-8,11,13-triene [32].

Another work on ethanolic stem extract also reported three major components in L. zeylanica, namely- (-)-epiloliolide, leuctriterpencoside and, (E)-4-((1S, 3R, 4R)-1-hydroxy-4,5,5-trimethyl-7-oxabicyclo [4.1.0] heptan-1-yl) but-1-en-3one [33].

Moreover, GC-MS analysis of essential oil collected from L. zeylanica seeds confirmed a couple of components- oleic acid, hexadecanoic acid, 1-octene-3-ol, caryophyllene and, 2,4,6-trimethyl-1,3,6-heptatriene [34].

A recent study on ethanol extract of L. zeylanica (whole plants) explored a total of 30 compounds, with a completely new isomer of norditerpenoid [35]. Among all components, flavonoids and terpenoids were the major ones. The reported components include- three flavonoid glycosides (torosaflavone A, apigenin-7-0-(6"-E-p-coumaroyl)- $\beta$-Dglucopyranoside and, drymariatin C), six flavonoids (daidzein, luteolin 3',4'-dimethyl ether, apigenin, tricin, chrysoeriol and, linarigenin), two phytosterols ( $\beta$-sitosterol and, stigmasterol), two phenylpropanoids (ethyl caffate and, evofolin B), two phthalate esters (dibutylphthalate and, dibutylterephthalate), two phenolic compounds (tyrosol and, catechol), five terpenoids (dehydrovomifoliol, cucumegastigmanes I, loliolide, isololiolide and, 4-hydroxyphthalide), one aliphatic glycoside (ethyl -D-galactopyranoside), one nucleobase (uracil), one amino acid (L-phenylalanine), two alkaloids (aurantiamide acetate and, $1 \mathrm{H}$-indole-3-carbaldehyde), one cytochalasin (cytochalasin $\mathrm{H}$ ) and, two norditerpenoids (6 $\beta$-Acetoxy-9 $\alpha, 13$-epoxy-16-norlabd-13E-en-15-al and, unnamed new compound: $\mathrm{C}_{21} \mathrm{H}_{32} \mathrm{O}_{4}$ ) [35]. 


\section{Pharmacological Potential of L. zeylanica}

\subsection{Analgesic potential}

Whole plant of L. zeylanica had been established to possess noteworthy analgesic properties [36]. A researcher group used methanolic extract and a number of soluble fractions to evaluate its efficacy in pain management. A well-known method (acetic acid induced writhing) was followed to settle the analgesic potential in peripheral area of mice [37]. Where the standard drug (Diclofenac sodium, $50 \mathrm{mg} / \mathrm{kg}$ ) reported $66.67 \%$ inhibition, crude extract of methanol, soluble fraction of petroleum ether, chloroform and ethyl acetate ensured a dose dependent inhibition of $17.67-32.00 \%$ and $22.00-40.00 \%$ at 100 and $200 \mathrm{mg} / \mathrm{kg}$ dose, respectively [36]. Central pathway related pain management potential of $L$. zeylanica was also confirmed by following an established method where pain sensation in tail portion of mice was applied by a source of non-stop heat [38]. The highest activity was noticed at $60 \mathrm{~min}$ of administration of the test materials. They certified a quantity dependent elongation of tail flicking time of $5.53-17.40 \%$ (at $100 \mathrm{mg} / \mathrm{kg}$ ) and $14.15-$ $25.53 \%$ (at $200 \mathrm{mg} / \mathrm{kg}$ ), where the standard drug (Morphine, $2 \mathrm{mg} / \mathrm{kg}$ ) showed 82.28\% elongation [36].

Peripheral pathway related pain controlling potential in mice was also reported by another research team [39]. They administered ethanolic extract of L. zeylanica plant at 250 and $500 \mathrm{mg} / \mathrm{kg}$ dose with Diclofenac as standard at $25 \mathrm{mg} / \mathrm{kg}$. The test models yielded an inhibition of 54.8-65.6\% ( $\mathrm{p}<0.001)$ where Diclofenac exhibited $55.2 \%$ inhibition of writhing [39].

\subsection{Anti-oxidative potential}

Leaves of L. zeylanica (extract of 100\% methanol) had proven its significant potential against oxidative injury caused by hydrogen peroxide and ethanol in liver tissue of rats [40]. An established technique was followed to observe the variation of levels of common liver enzymes [41]. The extract reported a noteworthy reduction of alanine aminotransferase $(\sim 13-15 \%)$ and aspartate aminotransferase $(\sim 8-10 \%)$. This study also estimated two antioxidant phytoconstituents- flavonoids and polyphenols content as $15.69 \pm 2.2 \mu \mathrm{g} \mathrm{QE} / \mathrm{mg}$ and $74.32 \pm 4.6 \mu \mathrm{g}$ of PE$/ \mathrm{mg}$ of extract, respectively by using previously defined procedures [40].

In another study, extract of methanol and different fractionates of L. zeylanica whole plants demonstrated significant antioxidative potential against a destructive free radical, DPPH (2,2-diphenyl-1-picrylhydrazyl [36, 42]. Crude extract,

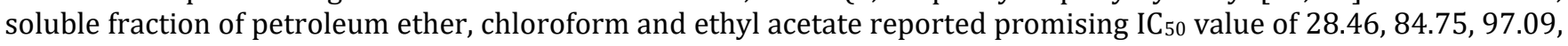
and $65.61 \mu \mathrm{g} / \mathrm{ml}$, respectively, where the result for standard drug (butylated hydroxytoluene) was $19.61 \mu \mathrm{g} / \mathrm{ml}$ [36].

A hopeful outcome supporting the antioxidative property of L. zeylanica was also described where ascorbic acid was the standard treatment $[39,43]$. Crude extract of ethanol and the standard agent (butylated hydroxytoluene) displayed an IC 50 value of 62.9 and $14.9 \mu \mathrm{g} / \mathrm{ml}$, respectively [39].

\subsection{Anti-microbial potential}

Globally, several studies had been conducted by following the well-established disc diffusion techniques with or without slight modifications to confirm the anti-microbial effect of L. zeylanica [44-47]. Abdullah et al. explored that the methanolic leaf extract $(70 \mu \mathrm{g} / \mu \mathrm{L}$ per well) gave a clear zone of 10.6 and $14.8 \mathrm{~mm}$ for $E$. coli and $S$. aureus, respectively. Here, Gentamicin formed 15.0 (E. coli) and $16.4 \mathrm{~mm}$ (S. aureus) clear zone [48]. Another study pronounced that ethanolic extract ( $600 \mu \mathrm{g} / \mathrm{disc}$ ) of L. zeylanica yielded $10-21 \mathrm{~mm}$ inhibition zone against some bacteria [39]. This result reported L. zeylanica as possessing mild-moderate potential compared to the standard agent, Amikacin (30 $\mu \mathrm{g} / \mathrm{disc}, 22-31 \mathrm{~mm}$ inhibition zone) [39].

Methanolic leaf extract $(20 \mu \mathrm{g} / \mu \mathrm{L}$ per well) was confirmed to have antifungal potential against penicillium $s p$., Trichophyton mentagrophytes, Candida albicans and Aspergillus flavus producing 4.0-10.0 mm inhibition zone where Clotrimazole (20 $\mathrm{\mu g} / \mathrm{disc})$ created 9.0-10.5 mm clear zone [15].

Although the antimicrobial potential was well established by some studies, two research teams found insignificant or negligible activities of whole plants of L. zeylanica [31,36].

\subsection{Sedative-hypnotic potential}

L. zeylanica showed its possible medicinal importance regarding neuropharmacological potential [39]. A research conducted by following previously recognized actions revealed that ethanol extract had substantial sedative-hypnotic potential $[39,49,50] .250$ and $500 \mathrm{mg} / \mathrm{kg}$ dose confirmed sleeping in tested mice after 42.6 and $37.2 \mathrm{~min}$ of application 
of the extract, respectively which could be measured as moderate action in comparison to the standard agent, Sodium phenobarbitone (25.8 $\mathrm{min}, 25 \mathrm{mg} / \mathrm{kg}$ dose) [39]. Tested preparations also ensured good sleeping time of 48.4 and 21.0 min at 250 and $500 \mathrm{mg} / \mathrm{kg}$ dose, respectively where the standard treatment presented a total sleeping period of 58.6 $\min [39]$.

\subsection{Anti-inflammatory potential}

Dichloromethane whole plant extract of L. zeylanica disclosed its anti-inflammatory potential by hindering the effect of 5-LO (5-lipoxygenase) and mPGES-1 (microsomal prostaglandin $\mathrm{E}_{2}$ synthase-1) in a study undergoing some renowned procedures [31, 51-53]. The extract inhibited the activity of 5-LO in isolated human cells (neutrophils) with $5.5 \mu \mathrm{g} / \mathrm{ml}$ IC 50 value which was noteworthy compared to that of the reference control (Zileuton), $0.13 \mu \mathrm{g} / \mathrm{ml}$ (equivalent to 0.55 $\mu \mathrm{M}$ ). This potential was rechecked by using the test preparations on recombinant 5-LO. In this case, Zileuton and the extract displayed an IC 50 value of 0.11 and $2.2 \mu \mathrm{g} / \mathrm{ml}$, respectively [31]. Formation of PGE $_{2}$ (prostaglandin E2), a proinflammatory substance, can be stopped by inhibiting mPGES-1 [54]. In a part of the aforementioned study, L. zeylanica presented its mPGES-1 blocking potential with $0.4 \mu \mathrm{g} / \mathrm{ml} \mathrm{IC} 50$ value where the reference inhibitor (MK-886) yielded an $\mathrm{IC}_{50}$ value of $2.2 \mu \mathrm{M}$ [31].

Table 1 Pharmacological potentials of L. zeylanica

\begin{tabular}{|c|c|c|c|}
\hline $\begin{array}{c}\text { Reported } \\
\text { Pharmacological Effects }\end{array}$ & $\begin{array}{l}\text { Type of Plant } \\
\text { Samples }\end{array}$ & Preparations & Reference(s) \\
\hline \multirow{2}{*}{$\begin{array}{l}\text { Analgesic } \quad \text { activity } \\
\text { (peripheral) }\end{array}$} & Whole plants & $\begin{array}{l}\text { Methanol extract; soluble fraction of } \\
\text { petroleum ether, chloroform and ethyl acetate }\end{array}$ & 36 \\
\hline & Whole plants & Ethanol extract & 39 \\
\hline Analgesic activity (central) & Whole plants & $\begin{array}{l}\text { Methanol extract; soluble fraction of } \\
\text { petroleum ether, chloroform and ethyl acetate }\end{array}$ & 36 \\
\hline \multirow{3}{*}{ Antioxidative activity } & Whole plants & $\begin{array}{l}\text { Methanol extract; soluble fraction of } \\
\text { petroleum ether, chloroform and ethyl acetate }\end{array}$ & 36 \\
\hline & Whole plants & Ethanol extract & 39 \\
\hline & Leaves & Methanol extract & 40 \\
\hline \multirow{2}{*}{ Anti-microbial activity } & Leaves & Methanol extract & 15,48 \\
\hline & Whole plants & Ethanol extract & 39 \\
\hline Sedative-hypnotic activity & Whole plants & Ethanol extract & 39 \\
\hline Anti-inflammatory activity & Whole plants & Dichloromethane extract & 31 \\
\hline Anti-gout activity & Whole plants & Dichloromethane extract & 31 \\
\hline Thrombolytic activity & Leaves & Ethanol extract & 56 \\
\hline Photoprotective activity & Leaves & Methanol extract & 58 \\
\hline
\end{tabular}

\subsection{Anti-gout potential}

Dichloromethane extract of L. zeylanica whole plants unveiled its inhibitory potential against a major causative enzyme of gout, XO (xanthine oxidase) in a research work conducted by a formerly established method [31, 55]. IC 50 values for the extract and standard application (Allopurinol) were 47.5 and $16.8 \mu \mathrm{g} / \mathrm{ml}$, respectively which specified moderate type anti-gout property of L. zeylanica [31].

\subsection{Thrombolytic potential}

For clot lysis, L. zeylanica leaf (extract of ethanol) had demonstrated its importance in an exploration led according to a previously established description [56,57]. Where Streptokinase (standard) presented an ability of clot lysis in 85.77\% cases, the experimental extract depicted that capability in $55.82 \%$ samples. This outcome established L. zeylanica as moderately effective in the lysis of thrombus [56]. 


\subsection{Photoprotective potential}

A study team explored sun protection potential of methanol extract of L. zeylanica leaf where Mansur equation was used to calculate SPF (sun protection factor) of the preparations $[58,59]$. The crude extract displayed higher SPF value (39.8 \pm 0.35 ) than that of two commercial sunscreen creams, SC1 (TiO2+benzophenone-4, SPF 10.7 \pm 0.07 ) and SC2 (Aloe+Sandlewood+Ficus, SPF $18.6 \pm 0.01)$. Leaf extract of Aloe vera also reported less SPF value (28.86 \pm 0.11$)$ than the extract. All these outcomes strengthened the standing of L. zeylanica as a robust source of photoprotective agents [58].

\section{Conclusion}

Folkloric system always opens a new window for the discovery and establishment of new entities in existing therapeutic approaches. Usually, when an explorer team finds the authenticity of a traditional practice of any medicinal plant, it becomes more encouraged to isolate the phytochemicals responsible for that usage. This process results in new hopes for the patients resistant/less responsive to the current medicaments. For this reason, interest on natural plants are gradually increasing. L. zeylanica is a widely used plant in folkloric system. Some of its local practices have already been justified that confirm its enormous potential to manage pain, oxidative damage, microbial infections, inflammatory conditions, insomnia, anxiety, gout, blood clotting and UV (ultraviolet) rays related damages. A number of different carbohydrates, glycosides, flavonoids, steroids etc. have been traced in crude preparations of L. zeylanica. Proper linking of these substances with the reported pharmacological actions and local practices of L. zeylanica will draw a map to synthesize lead molecules. However, A substantial number of traditional uses are still to be verified and more advanced approaches are needed to recognize and isolate all the conceivable phytoconstituents of L. zeylanica for unveiling new grounds for the drug discoverers.

\section{Compliance with ethical standards}

\section{Acknowledgments}

The authors would like to thank those people who sincerely contributed to make this study resourceful.

\section{Disclosure of conflict of interest}

The authors declare no conflict of interest.

\section{References}

[1] Rafe MR, Ahsan M, Hasan CM, Masud MM. Chemical and Biological Studies of Leaf Extract of Dendrophthoe falcata Linn. Dhaka University Journal of Pharmaceutical Sciences. 2017; 16(2): 215-219.

[2] Prabhadevi V, Sahaya SS, Johnson M, Venkatramani B, Janakiraman N. Phytochemical studies on Allamanda cathartica L. using GC-MS. Asian Pacific Journal of Tropical Biomedicine. 2012; 2(2): S550-554.

[3] Muhammad A. Therapeutic flora in Holy Quran. African Journal of History and Culture. 2014; 6(9): 141-148.

[4] Dhar AS, Rahman M, Rafe MR, Molla MI. Assessment of antidepressant and sedative-hypnotic activities of methanolic crude extracts of Stephania japonica (Thunb.) Miers. Whole plants. Current Issues in Pharmacy and Medical Sciences. 2020; 33(1): 51-55.

[5] Chouhan HS, Singh SK. A review of plants of genus Leucas. Journal of Pharmacognosy and Phytotherapy. 2011; 3(3): 13-26.

[6] Jebin R, Molla MI, Chowdhury SM, Rafe MR. Antidepressant and sedative-hypnotic activities of methanolic extract of grewia asiatica Linn. Leaves in Mice. Bangladesh Pharmaceutical Journal. 2019; 22(2): 185-191.

[7] Balunas MJ, Kinghorn AD. Drug discovery from medicinal plants. Life sciences. 2005; 78(5): 431-441.

[8] Yamamoto J, Yamada K, Naemura A, Yamashita T, Arai R. Testing various herbs for antithrombotic effect. Nutrition. 2005; 21(5): 580-587.

[9] Li Z, Wang H, Li J, Zhang G, Gao C. Basic and clinical study on the antithrombotic mechanism of glycosaminoglycan extracted from sea cucumber. Chinese Medical Journal. 2000; 113(8): 706-711.

[10] Briggs WH, Folts JD, Osman HE, Goldman IL. Administration of raw onion inhibits platelet-mediated thrombosis in dogs. The Journal of nutrition. 2001; 131(10): 2619-2622. 
[11] Demrow HS, Slane PR, Folts JD. Administration of wine and grape juice inhibits in vivo platelet activity and thrombosis in stenosed canine coronary arteries. Circulation. 1995; 91(4): 1182-1188.

[12] Hedge IC. Labiatae. In: Flora of Pakistan. Ali SI, Nasir YJ (Ed). University of Karachi, Karachi. $1990 ; 192$.

[13] Khanam M, Hassan MA. A critical study of the genus Leucas R. Br. (Lamiaceae) from Bangladesh. Bangladesh Journal of Plant Taxonomy. 2005; 12(1): 1-10.

[14] Jayaweera, DMA. Medicinal plants (Indigenous and exotic) used in Ceylon, Part III. National Science Council, Sri Lanka. 1980.

[15] Babu A, Mohamed MS, Jaikumar K, Anand D, Saravanan P. In-vitro antifungal activity of leaf extracts of Leucas aspera and Leucas zeylanica. International Journal of Pharmaceutical Sciences and Research. 2016; 7(2): 752.

[16] Uddin MZ, Emran TB, Nath AK, Jenny A, Dutta M, Morshed M. Thrombolytic activities of Spilanthes calva and Leucas zeylanica. Mol Clin Phol. 2013; 4: 32-37.

[17] Yusuf M, Wahab MA, Yousuf MD, Chowdhury JU, Begum J. Some tribal medicinal plants of Chittagong hill tracts, Bangladesh. Bangladesh Journal of Plant Taxonomy. 2007; 14(2): 117-128.

[18] Rajakaruna N, Harris CS, Towers GH. Antimicrobial activity of plants collected from serpentine outcrops in Sri Lanka. Pharmaceutical Biology. 2002; 40(3): 235-244.

[19] Harborne JB, Baxter H, Moss GP. Phytochemical dictionary: A handbook of bioactive compounds from plants. London: Tylor \& Francis Ltd. 1993; 773.

[20] Chopra RN, Nayar SL, Chopra IC. In Glossary of Indian medicinal plants, National Institute of Science Communication, New Delhi, India, 169 Cragg, GM and Newman, DJ (2005). Plants as a source of anticancer agents. J Ethnopharmacology. 1996; 100(1-2): 72-79.

[21] CAIUS JF. The medicinal and poisonous plants of India. Scientific Publications, Jodhpur, India. 1986.

[22] Ediriweera S. Effect of decoction of Leucas zeylanica in worm infestation with special reference to Enterobius vermicularis. Journal of Ayurveda and Holistic Medicine (JAHM). 2014; 2(3): 11-17.

[23] Jain D, Baheti AM, Jain SR, Khandelwal KR. Use of medicinal plants among tribes in Satpuda region of Dhule and Jalgaon district of Maharastra- An ethnobotanical survey. Indian J. Tradit. Know. 2010; 9: 152-157.

[24] Yusuf M, Wahab MA, Yousuf MD, Chowdhury JU, Begum J. Some tribal medicinal plants of Chittagong hill tracts, Bangladesh. Bangladesh Journal of Plant Taxonomy. 2007; 14(2): 117-128.

[25] Yusuf M, Wahab MA, Chowdhury JU, Begum J. Ethno-medico-botanical knowledge from Kaukhali proper and Betbunia of Rangamati District. Bangladesh Journal of Plant Taxonomy. 2006; 13(1): 55-61.

[26] Shirazi AM. Studies on Leucas aspera. Indian j pharm. 1947; 9: 116-117.

[27] Ghani A. Medicinal plants of Bangladesh: chemical constituents and uses. Asiatic society of Bangladesh, Dhaka, Bangladesh. 1998.

[28] Trease GE, Evans WC. A Text Book of Pharmacognosy. 13th ed. Cambridge University Press. London, England. 1989; 546.

[29] Paul S, Saha D. Pharmacognostic studies on methanolic extract of the aerial part of Leucas zeylanica. Asian J Pharm Res. 2012; 2: 142-143.

[30] Radhika B, Srilekha T, Chaitanya S. Pharmacognostic and Preliminary Phytochemical Evaluation of the leaves of Lucas zeylanica. Int J Biomed Investig. 2018; 1: 102.

[31] Napagoda M, Gerstmeier J, Butschek H, Lorenz S, Kanatiwela D, Qader M, Nagahawatte A, De Soyza S, Wijayaratne GB, Svatoš A, Jayasinghe L. Lipophilic extracts of Leucas zeylanica, a multi-purpose medicinal plant in the tropics, inhibit key enzymes involved in inflammation and gout. Journal of ethnopharmacology. 2018; 224: $474-481$.

[32] Zhang X, Gui M, Zhang C, Chen C, Yu L, Liu J. Leucasinoside: A new abietane diterpenoid glycoside from Leucas zeylanica. Records of Natural Products. 2016; 10(5): 645.

[33] Chen GY, Zhang B, Zhao T, Nidhal N, Jia-Li W, Zhou XM, Chun-Yan D. A new triterpenoid glucoside from Leucas zeylanica. Natural product research. 2020; 34(13): 1874-1878.

[34] Tian GH, Liu CF, Wei C, Lai PH. Study on Essential Oil Obtained from the Seed of Leucas zeylanica [J]. Amino Acids \& Biotic Resources. 2009; 2. 
[35] Nidhal N, Zhou XM, Chen G, Zhang B, Han C, Song X. Chemical constituents of Leucas zeylanica and their chemotaxonomic significance. Biochemical Systematics and Ecology. 2020; 89: 104006.

[36] Islam MM, Parvin ES, Zahir RS, Al MZ. Methanolic extracts and different fractions of whole plants of Leucas zeylanica show promising analgesic and antioxidative activities. Egyptian Pharmaceutical Journal. 2020; 19(3): 260-265.

[37] Ahmed M, Shikha HA, Sadhu SK, Rahman MT, Datta BK. Analgesic, diuretic, and anti-inflammatory principle from Scoparia dulcis. Die Pharmazie. 2001; 56(8): 657-660.

[38] Pizziketti RJ, Pressman NS, Geller EB, Cowan A, Adler MW. Rat cold water tail-flick: a novel analgesic test that distinguishes opioid agonists from mixed agonist-antagonists. European journal of pharmacology. 1985; 119(12): 23-29.

[39] Islam MA, Biswas NN. Assessment of phytochemical and pharmacological activities of Leucas zeylanica (L) R. Br. (Family: Lamiaceae). Hamdard Medicus. 2010; 53: 19-29.

[40] Hossain S, Rahman M, Fatima N, Haque M, Islam J. Leucas zeylanica (L.) R. Br. protects ethanol and hydrogen peroxide-induced oxidative stress on hepatic tissue of rats. International Current Pharmaceutical Journal. 2013; 2(9): 148-151.

[41] Lowry OH, Rosebrough NJ, Farr AL, Randall RJ. Protein measurement with the Folin-phenol reagent. Journal of biological chemistry. 1951; 193: 265-275.

[42] Brand-Williams W, Cuvelier ME, Berset CL. Use of a free radical method to evaluate antioxidant activity. LWTFood science and Technology. 1995; 28(1): 25-30.

[43] Gupta M, Mazumdar UK, Sivahkumar T, Vamis ML, Karki S, Sambathkumar R, Manikandan L. Antioxidant and anti-inflammatory activities of Acalypha fruticosa. Nigerian Journal of Natural Products and Medicine. 2003; 7: 25-29.

[44] Bauer AW, Kirby WM, Sherris JC, Turck M. Antibiotic Susceptibility Testing by a Standardized Single Disk Method. American journal of clinical pathology. 1966; 45(4): 493-496.

[45] Ahmed F, Das PK, Islam MA, Rahman KM, Rahman MM, Selim MS. Antibacterial activity of Cordyline terminalis. Kunth. Leaves. J. Med. Sci. 2003; 3(5-6): 418-422.

[46] Andrews JM. Determination of minimum inhibitory concentrations. Journal of antimicrobial chemotherapy. 2001; 48(1): 5-16.

[47] Eldeen IM, Van Staden J. Antimycobacterial activity of some trees used in South African traditional medicine. South African Journal of Botany. 2007; 73(2): 248-251.

[48] Abdullah F, Nasir SN, Han DK, Appalasamy S, nor MM, Rak AE. Potential of Leucas zeylanica extract to eliminate E. coli and S. aureus in Corbicula fluminea ("Etak") tissue. Malaysian Journal of Fundamental and Applied Sciences. 2019; 15(4): 597-599.

[49] Chatterjee TK. Handbook of laboratory Mice and Rats, $1^{\text {st }}$ Edition. Department of Pharmaceutical Technology, Jadavpur University, India. 1993; 157.

[50] Dandiya PC, Cullumbine H. Studies on Acorus calamus (III): some pharmacological actions of the volatile oil. Journal of Pharmacology and Experimental Therapeutics. 1959; 125(4): 353-359.

[51] Koeberle A, Zettl H, Greiner C, Wurglics M, Schubert-Zsilavecz M, Werz O. Pirinixic acid derivatives as novel dual inhibitors of microsomal prostaglandin E2 synthase-1 and 5-lipoxygenase. Journal of medicinal chemistry. 2008; 51(24): 8068-8076.

[52] Werz O. Inhibition of 5-lipoxygenase product synthesis by natural compounds of plant origin. Planta medica. 2007; 73(13): 1331-1357.

[53] Fischer L, Szellas D, Rådmark O, Steinhilber D, Werz O. Phosphorylation-and stimulus-dependent inhibition of cellular 5-lipoxygenase activity by nonredox-type inhibitors. The FASEB journal. 2003; 17(8): 1-24.

[54] Koeberle A, Werz O. Perspective of microsomal prostaglandin E2 synthase-1 as drug target in inflammationrelated disorders. Biochemical pharmacology. 2015; 98(1): 1-15.

[55] Khan KM, Khan M, Karim A, Taha M, Ambreen N, Gojayev A, Perveen S, Choudhary MI. Xanthine oxidase inhibition by 5-aryledene N, N'-dimethylbarbituric acid derivatives. J Chem Soc Pak. 2013; 35: 495-498. 
[56] Uddin MZ, Emran TB, Nath AK, Jenny A, Dutta M, Morshed M. Thrombolytic activities of Spilanthes calva and Leucas zeylanica. Mol Clin Phol. 2013; 4: 32-37.

[57] Prasad S, Kashyap RS, Deopujari JY, Purohit HJ, Taori GM, Daginawala HF. Effect of Fagonia arabica (Dhamasa) on in vitro thrombolysis. BMC Complementary and Alternative Medicine. 2007; 7(1): 1-6.

[58] Napagoda MT, Malkanthi BM, Abayawardana SA, Qader MM, Jayasinghe L. Photoprotective potential in some medicinal plants used to treat skin diseases in Sri Lanka. BMC complementary and alternative medicine. 2016 16(1): 1-6.

[59] Mansur JS, Breder MN, Mansur MC, Azulay RD. Determination of sun protection factor by spectrophotometry. A Bras Dermatol. 1986; 61: 121-124. 